\title{
HUBUNGAN KARAKTERISTIK PASIEN KEHILANGAN GIGI TETAP DENGAN MINAT PEMAKAIAN GIGI TIRUAN SEBAGIAN LEPASAN
}

\author{
${ }^{1}$ Anie Kristiani \\ ${ }^{1}$ Dosen Poltekkes Kemnekes Tasikmalaya
}

\begin{abstract}
Abstrak
Tujuan penelitian ini untuk mengetahui hubungan karakteristik pasien kehilangan gigi tetap dengan minat pemakaian gigi tiruan sebagian lepasan di Poliklinik Gigi RSUD Kota Tasikmalaya tahun 2013. Metode penelitian yang digunakan deskriptif analitik dengan pendekatan cross sectional. Populasi penelitian adalah seluruh pasien yang melakukan pencabutan gigi di RSUD Kota Tasikmalaya periode Pebruari 2013 sebanyak 112 orang dengan teknik pengambilan sampel accidental dengan jumlah 34 orang. Hasil penelitian menunjukkan umur pasien kehilangan gigi tetap di Poliklinik Gigi RSUD Kota Tasikmalaya sebagian besar pada kategori umur $36-45$ sebanyak 22 orang $(55,9 \%)$, jenis kelamin terbanyak pada jenis kelamin perempuan sebanyak 21 orang $(61,8 \%)$, pendidikan tinggi sebanyak 17 orang $(50 \%)$, jenis pekerjaan terbanyak pada kategori pekerjaan memerlukan penampilan sebanyak 26 orang $(76,5 \%)$, sosial ekonomi pasien terbanyak pada kategori pendapatan tinggi sebanyak 20 orang $(58,8 \%)$, ada hubungan umur dengan minat pemakaian gigi tiruan sebagian lepasan nilai signifikan $p$ value sebesar $0,007<0,05$, ada hubungan jenis kelamin minat pemakaian gigi tiruan sebagian lepasan dengan nilai signifikan $p$ value sebesar $0,012<0,05$, ada hubungan pendidikan dengan minat pemakaian gigi tiruan sebagian lepasan di dengan nilai signifikan $p$ value sebesar $0,0001<0,05$ dan ada hubungan jenis pekerjaan dengan minat pemakaian gigi tiruan sebagian lepasan dengan nilai signifikan $p$ value sebesar 0,0001 $<0,05$ dan ada hubungan sosial ekonomi dengan minat pemakaian gigi tiruan sebagian lepasan dengan nilai signifikan $p$ value sebesar $0,004<0,05$. Kesimpulan terdapat hubungan karakeristik pasien (umur, jenis kelamin, pendidikan, jenis pekerjaan, sosial ekonomi) yang kehilangan gigi tetap dengan minat pemakaian gigi tiruan sebagian lepasan di Poliklinik Gigi RSUD Kota Tasikmalaya tahun 2013.
\end{abstract}

Kata kunci : Karakteristik Pasien, Minat, Gigi Tiruan.

\begin{abstract}
The purpose of this study to know the relationship of the characteristics of patients lost interest in the use of permanent teeth with removable partial dentures in Dental Polyclinic Hospital Tasikmalaya City 2013. The method used is descriptive analytic method with cross sectional approach. The population in this study were all patients undergoing dental extractions in Hospital Tasikmalaya City February 2013 period were 112 people with accidental sampling technique as much 34 people. Results showed patients lost age permanent teeth Dental Polyclinic Hospital in Tasikmalaya largely on the age category 36-45 were 22 people (55.94\%), the highest sex female sex as many as 21 people (61.8\%), higher education as 17 people (50\%), type in the job category most jobs require the appearance of as many as 26 people (76.5\%), patients in poor socio economic higher income category by 20 people (58.8\%), there was relationship age with interest in a the use of dental removable $\rho$ value significant of $0,007<$ 0,05 , there was relations gender with interest in the use of removable partial dentures with $\rho$ value significant of $0,012<0,05$, there was a relation between education and interest in the use of removable partial dentures in the significant value $\rho$ value of $0,0001<0,05$, and there wasrelation with the type of work with interests use of removable partial dentures with significant $\rho$ value of 0,0001 $<0,05$ and there was socio economic relations with interest value of the use of removable partial dentures with significant value 0,004 $<0,05$. Conclusion there is a relationship characterized the patient (age, sex, education, occupation, socioeconomic) with missing teeth fixed to interest the use of removable partial dentures in Tasikmalaya City Hospital Dental Clinic in 2013.
\end{abstract}

Keywords: Patient characteristics, Interests, Denture. 


\section{PENDAHULUAN}

Kehilangan gigi di Indonesia pada kelompok umur 45-54 tahun sebesar 1,8\%. Seseorang yang telah kehilangan gigi hendaknya ditanggulangi dengan pemakaian gigi tiruan. Faktor-faktor yang berhubungan dengan minat pemakaian gigi sebagian lepasan diantaranya umur, jenis kelamin, pendidikan, jenis pekerjaan dan pendapatan.

Hasil laporan nasional RISKESDAS 2007, lima provinsi dengan prevalensi masalah gigi dan mulut tertinggi yaitu Gorontalo (33,1\%), Sulawesi Tengah $(31,2 \%)$, DI Aceh $(30,5)$, Sulawesi Utara $(29,8 \%)$ dan Kalimantan Selatan $(29,2 \%)$. Kehilangan gigi molar permanen pertama bawah memiliki prevalensi yang cukup tinggi. Pada penelitian yang telah dilakukan oleh Janjua dkk, (2014) persentase pencabutan molar pertama bawah kiri sebesar $32,1 \%$ dan pencabutan molar pertama bawah kanan sebesar 30,6\% yang kebanyakkan disebabkan oleh karies. Hal ini dikarenakan gigi molar permanen pertama bawah merupakan gigi tetap yang pertama kali erupsi sekitar umur 6-7 tahun pada periode gigi campuran. Gigi molar permanen pertama memainkan peran penting dalam mastikasi dan menentukan posisis erupsi gigi posterior yang lain agar menjadi oklusi yang benar. Kehilangan satu gigi terutama gigi molar permanen pertama bawah dapat menyebabkan fungsi lengkung rahang menurun sebesar $10 \%$ dan penurunan ini akan meningkat sebesar $30 \%$ jika penggantian gigi yang hilang tidak segera dilakukan.

\section{METODE PENELITIAN}

Metode yang digunakan adalah metode deskriptif analitik dengan pendekatan cross sectional. Populasi penelitian adalah seluruh pasien yang melakukan pencabutan gigi di RSUD Kota Tasikmalaya periode Pebruari 2013 sebanyak 112 orang dengan teknik pengambilan sampel accidental berjumlah 34 orang. Alat dan bahan yang digunakan adalah diagnostik set, format penelitian berupa kuesioner dan alat tulis.

\section{HASIL PENELITIAN}

Tabel 1. Distribusi Frekuensi Responden Berdasarkan Umur

\begin{tabular}{ccc}
\hline Umur (tahun) & $\mathbf{N}$ & $\%$ \\
\hline $25-35$ & 12 & 35,3 \\
\hline $36-45$ & 22 & 64,7 \\
\hline Total & 34 & 100 \\
\hline
\end{tabular}

Pada Tabel 1 dapat dilihat bahwa umur yang melakukan pencabutan gigi di RSUD Kota Tasikmalaya terbanyak pada kategori umur 36-45 sebanyak 22 orang $(64,7 \%)$.

Tabel 2. Distribusi Frekuensi Responden Berdasarkan Jenis Kelamin

\begin{tabular}{ccc}
\hline Jenis Kelamin & $\mathbf{N}$ & $\%$ \\
\hline Laki-laki & 13 & 38,2 \\
\hline Perempuan & 21 & 61,8 \\
\hline Total & 34 & 100 \\
\hline
\end{tabular}

Pada Tabel 2 dapat dilihat bahwa yang melakukan pencabutan gigi di RSUD Kota Tasikmalaya terbanyak pada jenis kelamin perempuan sebanyak 21 orang $(61,8 \%)$.

Tabel 3. Distribusi Frekuensi Responden Berdasarkan Pendidikan

\begin{tabular}{ccc}
\hline Pendidikan & $\mathbf{N}$ & $\%$ \\
\hline Rendah & 4 & 11,8 \\
\hline Menengah & 13 & 38,2 \\
\hline Tinggi & 17 & 50 \\
\hline Total & 34 & 100 \\
\hline
\end{tabular}

Pada Tabel 3 dapat dilihat bahwa pendidikan responden yang melakukan pencabutan gigi di RSUD Kota Tasikmalaya terbanyak pada pendidikan tinggi sebanyak 17 orang $(50 \%)$ 
Tabel 4. Distribusi Frekuensi Responden Berdasarkan Jenis Pekerjaan

\begin{tabular}{ccc}
\hline Jenis Pekerjaan & N & $\%$ \\
\hline $\begin{array}{c}\text { Tidak memerlukan } \\
\text { penampilan }\end{array}$ & 8 & 23,5 \\
\hline Memerlukan penampilan & 26 & 76,5 \\
\hline Total & 34 & 100 \\
\hline
\end{tabular}

Pada Tabel 4 dapat dilihat bahwa jenis pekerjaan yang melakukan pencabutan gigi di RSUD Kota Tasikmalaya terbanyak pada kategori pekerjaan memerlukan penampilan sebanyak 26 orang $(76,5 \%)$.

Tabel 5. Distribusi Frekuensi Responden Berdasarkan Pendapatan

\begin{tabular}{ccc}
\hline \multicolumn{3}{c}{ Berdasarkan Pendapatan } \\
\hline Pendapatan & N & $\%$ \\
\hline Rendah (< UMR) & 4 & 11,8 \\
\hline Cukup (UMR) & 10 & 29,4 \\
\hline Tinggi (> UMR) & 20 & 58,8 \\
\hline Total & 34 & 100 \\
\hline
\end{tabular}

Pada Tabel 5 dapat dilihat bahwa pendapatan responden terbanyak pada kategori pendapatan tinggi sebanyak 20 orang $(58,8 \%)$.

Tabel 6. Distribusi Frekuensi Responden Berdasarkan Minat Pemakaian

\begin{tabular}{ccc}
\hline Minat Pemakaian & N & $\%$ \\
\hline Rendah & 6 & 17,6 \\
\hline Tinggi & 28 & 82,4 \\
\hline Total & 34 & 100
\end{tabular}

Pada Tabel 6 dapat dilihat bahwa minat pemakaian gigi tiruan sebagaian lepasan di RSUD Kota Tasikmalaya terbanyak pada kategori minat tinggi sebanyak 28 orang ( $82,4 \%)$.

Hasil analisis bivariat dilakukan untuk mengetahui faktor-faktor umur, jenis kelamin, pendidikan, jenis pekerjaan dan pendapatan dengan minat pemakaian gigi tiruan sebagian lepasan.

Berdasarkan tabel 7 dapat dilihat bahwa umur kurang dari 36 tahun dengan minat rendah untuk pemakaian gigi sebagian lepasan sebanyak 5 orang
$(41,7 \%)$ dan umur $36-45$ tahun dengan minat tinggi untuk pemakaian gigi sebagaian lepasan sebanyak 21 orang $(95,5 \%)$.

Tabel 7. Hubungan Umur Pasien Kehilangan Gigi Tetap dengan Minat Pemakaian Gigi Tiruan Sebagian Lepasan

\begin{tabular}{cccc}
\hline \multirow{2}{*}{$\begin{array}{c}\text { Umur } \\
\text { (tahun) }\end{array}$} & \multicolumn{2}{c}{ Minat } & Total \\
\cline { 2 - 3 } & Rendah & Tinggi & \\
\hline $25-35$ & 5 & 7 & 12 \\
\hline $36-45$ & 1 & 21 & 22 \\
\hline Total & 6 & 28 & 34 \\
\hline
\end{tabular}

Uji statistik chi square dengan tingkat ketelitian 0,05 menunjukkan nilai $\chi^{2}$ sebesar 7,362 dengan nilai signifikan $p$ value sebesar 0,007 0,05 artinya Ho ditolak dan Ha diterima. Hal ini menunjukkan terdapat hubungan umur pasien kehilangan gigi tetap dengan minat pemakaian gigi tiruan sebagian lepasan di Poliklinik Gigi RSUD Tasikmalaya.

Tabel 8. Hubungan Jenis Kelamin Pasien Kehilangan Gigi Tetap dengan Minat Pemakaian Gigi Tiruan Sebagian Lepasan

\begin{tabular}{|c|c|c|c|}
\hline \multirow{2}{*}{$\begin{array}{l}\text { Jenis } \\
\text { Kelamin }\end{array}$} & \multicolumn{2}{|c|}{ Minat } & \multirow{2}{*}{ Total } \\
\hline & Rendah & Tinggi & \\
\hline Laki-laki & 5 & 8 & 13 \\
\hline Perempuan & 1 & 20 & 21 \\
\hline Total & 6 & 28 & 34 \\
\hline
\end{tabular}

Berdasarkan tabel 8 dapat dilihat bahwa jenis kelamin laki-laki dengan minat rendah untuk pemakaian gigi sebagian lepasan sebanyak 5 orang (38,5\%) dan jenis kelamin perempuan dengan minat tinggi untuk pemakaian gigi sebagaian lepasan sebanyak 20 orang $(95,2 \%)$.

Uji statistik chi square dengan tingkat ketelitian 0,05 menunjukkan nilai $\chi^{2}$ sebesar 6,275 dengan nilai signifikan $p$ value sebesar 0,012 <0,05 artinya Ho ditolak dan Ha diterima. Hal ini menunjukkan terdapat hubungan jenis kelamin pasien kehilangan gigi tetap dengan minat pemakaian gigi tiruan sebagian lepasan di Poliklinik Gigi RSUD Tasikmalaya. 
Tabel 9. Hubungan Pendidikan Pasien

Kehilangan Gigi Tetap dengan Minat

Pemakaian Gigi Tiruan Sebagian Lepasan

\begin{tabular}{cccc}
\hline \multirow{2}{*}{ Pendidikan } & \multicolumn{2}{c}{ Minat } & \multirow{2}{*}{ Total } \\
\cline { 2 - 3 } & Rendah & Tinggi & \\
\hline Menengah & 6 & 11 & 17 \\
\hline Tinggi & 0 & 17 & 17 \\
\hline Total & 6 & 28 & 34 \\
\hline
\end{tabular}

Berdasarkan tabel 9 dapat dilihat Uji statistik chi square dengan tingkat ketelitian 0,05 menunjukkan nilai $\chi^{2}$ sebesar 22,355 dengan nilai signifikan $\mathrm{p}$ value sebesar $0,0001<0,05$ artinya Ho ditolak dan $\mathrm{Ha}$ diterima. Hal ini menunjukkan terdapat hubungan pendidikan pasien kehilangan gigi tetap dengan minat pemakaian gigi tiruan sebagian lepasan di Poliklinik Gigi RSUD Tasikmalaya.

Tabel 10. Hubungan Jenis Pekerjaan Pasien Kehilangan Gigi Tetap dengan Minat Pemakaian Gigi Tiruan Sebagian Lepasan

\begin{tabular}{cccc}
\hline \multirow{2}{*}{$\begin{array}{c}\text { Jenis } \\
\text { pekerjaan }\end{array}$} & \multicolumn{2}{c}{ Minat } & Total \\
\cline { 2 - 3 } & Rendah & Tinggi & \\
\hline $\begin{array}{c}\text { Tidak } \\
\text { memerlukan } \\
\text { penampilan }\end{array}$ & 5 & 3 & 8 \\
\hline $\begin{array}{c}\text { Memerlukan } \\
\text { penampilan }\end{array}$ & 1 & 25 & 26 \\
\hline Total & 6 & 28 & 34
\end{tabular}

Berdasarkan tabel 10 dapat dilihat bahwa jenis pekerjaan tidak memerlukan penampilan dengan minat rendah untuk pemakaian gigi sebagian lepasan sebanyak 5 orang $(100 \%)$ dan jenis pekerjaan yang memerlukan penampilan dengan minat tinggi untuk pemakaian gigi sebagian lepasan sebanyak 25 orang $(96,2 \%)$.

Uji statistik chi square dengan tingkat ketelitian 0,05 menunjukkan nilai $\chi^{2}$ sebesar 14,482 dengan nilai signifikan $p$ value sebesar 0,0001<0,05 artinya Ho ditolak dan $\mathrm{Ha}$ diterima. Hal ini menunjukkan terdapat hubungan jenis pekerjaan pasien kehilangan gigi tetap dengan minat pemakaian gigi tiruan sebagian lepasan di Poliklinik Gigi RSUD Tasikmalaya.
Tabel 11. Hubungan Jenis Pekerjaan Pasien Kehilangan Gigi Tetap dengan Minat Pemakaian Gigi Tiruan Sebagian Lepasan

\begin{tabular}{|c|c|c|c|}
\hline \multirow{2}{*}{ Pendapatan } & \multicolumn{2}{|c|}{ Minat } & \multirow{2}{*}{ Total } \\
\hline & Rendah & Tinggi & \\
\hline Rendah & 3 & 1 & 4 \\
\hline Cukup & 2 & 8 & 10 \\
\hline Tinggi & 1 & 19 & 20 \\
\hline Total & 6 & 28 & 34 \\
\hline
\end{tabular}

Berdasarkan tabel 11 dapat dilihat bahwa pendapatan rendah dengan minat rendah untuk pemakaian gigi sebagian lepasan sebanyak 3 orang $(75 \%)$ dan pendpatan tinggi dengan minat tinggi untuk pemakaian gigi sebagaian lepasan sebanyak 19 orang (95\%).

Uji statistik chi square dengan tingkat ketelitian 0,05 menunjukkan nilai $\chi^{2}$ sebesar 11,293 dengan nilai signifikan $\mathrm{p}$ value sebesar 0,004 $<0,05$ artinya Ho ditolak dan Ha diterima. Hal ini menunjukkan terdapat hubungan pendapatan pasien kehilangan gigi tetap dengan minat pemakaian gigi tiruan sebagian lepasan di Poliklinik Gigi RSUD Tasikmalaya.

\section{PEMBAHASAN}

Hasil penelitian menunjukkan bahwa umur responden yang melakukan pencabutan gigi di RSUD Kota Tasikmalaya terbanyak pada kategori umur 36-45 sebanyak 22 orang (55.94\%) dan terdapat hubungan umur pasien kehilangan gigi tetap dengan minat pemakaian gigi tiruan sebagian lepasan dengan $p$ value sebesar $0,007<0,05$.

Pada RSUD Kota Tasikmalaya responden yang melakukan pencabutan gigi tetap banyak yang sudah bekerja baik swasta maupun PNS sehingga kebanyakan umur pasien di atas 36 tahun. Adanya hubungan umur dengan minat pemakaian gigi tiruan sebagian lepasan karena pada umur dewasa muda kehilangan gigi akan berpengaruh pada penampilan.

Menurut Mc. Cord (2004), kelompok umur dewasa muda mempunyai pola permintaan pelayanan kesehatan gigi yang 
lebih baik dibandingkan dengan kelompok umur yang lain, disebabkan oleh karena kelompok umur ini mempunyai kebutuhan akan perawatan kesehatan gigi yang lebih tinggi, berdasarkan pola kecendrungan menderita karies gigi tahap awal dan gejala awal dari kelainan jaringan gigi. Sebaliknya pada umur tua yang banyak menderita kehilangan gigi asli ternyata kurang menyadari kebutuhan perawatan gigi, sehingga mengakibatkan rendahnya permintaan akan perawatan gigi pada usia lanjut. Hendrartini (1995), menganalisis faktor-faktor yang mempengaruhi pemanfaatan pelayanan kesehatan gigi di RS Sardjito dan RS Bethesda, menyimpulkan bahwa faktor umur mempunyai pengaruh bermakna terhadap pemanfaatan pelayanan kesehatan gigi. Faktor umur mempengaruhi pada minat pemakaian gigi karena pada umur muda banyak memperhatikan kesehatan gigi yang akan menunjang pada penampilannya.

Hasil penelitian menunjukkan bahwa jenis kelamin responden yang melakukan pencabutan gigi di RSUD Kota Tasikmalaya terbanyak pada dengan jenis kelamin perempuan sebanyak 21 orang $(61,8 \%)$ dan terdapat hubungan jenis kelamin kehilangan gigi tetap dengan minat pemakaian gigi tiruan sebagian lepasan dengan $p$ value sebesar $0,012<0,05$. Perempuan yang melakukan pencabutan gigi tetap karena akan mempengaruhi pada penampilannya. Adanya hubungan jenis kelamin dengan minat pemakaian gigi tiruan sebagian lepasan karena jenis kelamin perempuan lebih memperhatikan penampilan dibandingkan dengan laki-laki. Motivasi itu bervariasi dari masing-masing individu dalam mengatasi masalah gigi diantaranya dipengaruhi oleh faktor jenis kelamin (Rikmasari, 2010).

Kunjungan pasien ke poliklinik gigi RSUD Kota Tasikmalaya untuk melakukan pencabutan gigi kebanyakan perempuan dan memiliki pekerjaan sebagai guru dan pegawai swasta yang sangat memerlukan penampilan dalam kegiatan sehari-hari.
Pendidikan responden yang melakukan pencabutan gigi di RSUD Kota Tasikmalaya terbanyak pada kategori pendidikan tinggi sebanyak 17 orang (50\%) dan terdapat hubungan pendidikan kehilangan gigi tetap dengan minat pemakaian gigi tiruan sebagian lepasan dengan $p$ value sebesar 0,0001<0,05.

Banyak pasien yang memiliki pendidikan perguruan tinggi. Jenjang pendidikan adalah tahapan pendidikan yang ditetapkan berdasarkan tingkat perkembangan, tujuan yang akan dicapai dan kemampuan yang dikembangkan. Adapun jenjang pendidikan: Rendah (tidak tamat SD, MI, SMP), Menengah (SMA) dan Perguruan tinggi (Depdiknas, 2011). Ada hubungan pendidikan dengan minat pemakaian gigi tiruan sebagian lepasan karena dengan pendidikan yang semakin tinggi kesadaran untuk memelihara kesehatan khususnya kesehatan gigi akan semakin baik. Menurut Notoatmodjo (2003), permintaan konsumen dalam pemanfaatan pelayanan kesehatan berhubungan dengan pendidikan dan perilaku masyarakat. Rendahnya pengetahuan dan kesadaran masyarakat terhadap kesehatan dan penyakit, dapat mengakibatkan penyakitpenyakit yang terjadi dalam masyarakat sering sulit terdeteksi. Bahkan kadangkadang masyarakat sulit atau tidak mau diperiksa dan diobati penyakitnya. Pendidikan pasien yang melakukan pencabutan gigi tetap kebanyakan memiliki pendidikan tinggi dan bekerja sebagai PNS maupun pegawai swasta yang mempunyai asuransi dalam untuk kesehatan khususnya pencabutan gigi.

Hasil penelitian menunjukkan bahwa jenis pekerjaan yang melakukan pencabutan gigi di RSUD Kota Tasikmalaya terbanyak pada kategori memerlukan penampilan sebanyak 26 orang $(50 \%)$ dan terdapat hubungan jenis pekerjaan yang kehilangan gigi tetap dengan minat pemakaian gigi tiruan sebagian lepasan dengan $p$ value sebesar $0,0001<0,05$. Terdapat hubungan jenis pekerjaan dengan minat pemakaian gigi tiruan sebagian lepasan karena adanya 
tuntutan pekerjaan yang harus memperhatikan penampilan dan jenis pekerjaan yang berhubungan dengan orang lain sehingga akan mempengaruhi pada penampilan pasien tersebut. Pekerjaan adalah suatu usaha yang dilakukan atau dikerjakan untuk mendapatkan hasil atau upah yang dapat dinilai dengan uang. Suatu pekerjaan, selalu terdapat tuntutan perubahan kebutuhan yang diperlukan untuk memegang pekerjaan yang mengarah ke sistem kerja yang otomatis. Pemenuhan tuntutan pekerjaan, dibutuhkan informasi yang lengkap dan cepat maka dari itu orang yang bekerja akan memiliki akses yang lebih baik tentang berbagai informasi (Hurlock, 2004). Keputusan seseorang untuk meminta pelayanan kesehatan salah satunya yaitu faktor predisposing, salah satunya faktor struktur sosial meliputi: jenis pekerjaan (Notoatmodjo, 2007).

Hasil penelitian menunjukkan bahwa pendapatan pasien yang melakukan pencabutan gigi di RSUD Kota Tasikmalaya terbanyak pada kategori pendapatan tinggi sebanyak 20 orang $(58,8 \%)$ dan terdapat hubungan jenis pekerjaan yang kehilangan gigi tetap dengan minat pemakaian gigi tiruan sebagian lepasan dengan $p$ value sebesar $0,004<0,05$. Kunjungan pasien yang datang ke Poliklinik RSUD kota Tasikmlaya kebanyakan memiliki pendapatan yang tinggi hal ini terlihat dari kunjungan karena banyak yang bekerja sebagai PNS dan pegawai swasta, selain itu menggunakan dengan asuransi kesehatan dapat meringankan biaya dalam pembuatan gigi giruan sebagian lepasan. Pendapatan pasien berhubungan dengan minat pemakaian gigi tiruan sebagian lepasan karena dengan pendapatan yang tinggi akan mampu untuk memelihara kesehatan gigi khususnya dalam pemakaian gigi tiruan sebagian lepasan. Pendapatan keluarga adalah jumlah penghasilan seluruh anggota keluarga. Pendapatan berhubungan langsung dengan kebutuhan-kebutuhan keluarga, penghasilan yang tinggi dan teratur membawa dampak positif bagi keluarga karena keseluruhan kebutuhan sandang, pangan, papan dan transportasi serta kesehatan dapat terpenuhi. Keluarga yang pendapatannya rendah akan mengakibatkan keluarga mengalami kerawanan dalam pemenuhan kebutuhan hidupnya yang salah satunya adalah pemeliharaan kesehatan (Keraf, 2001). Penelitian terdahulu melaporkan bahwa terdapat beberapa faktor yang mempengaruhi kesehatan gigi yaitu faktor psikologi (kecemasan perawatan) sosial (pekerjaan, pendidikan), pemahaman mengenai kesehatan dan demografi (Rikmasari 2010).

\section{KESIMPULAN}

1. Umur pasien kehilangan gigi tetap di Poliklinik Gigi RSUD Kota Tasikmalaya sebagian besar pada kategori umur 3645 sebanyak 22 orang (55.94\%).

2. Jenis kelamin pasien kehilangan gigi tetap di Poliklinik Gigi RSUD Kota Tasikmalaya terbanyak pada jenis kelamin perempuan sebanyak 21 orang $(61,8 \%)$.

3. Pendidikan pasien kehilangan gigi tetap di Poliklinik Gigi RSUD Kota Tasikmalaya terbanyak pada pendidikan tinggi sebanyak 17 orang $(50 \%)$.

4. Jenis pekerjaan pasien kehilangan gigi tetap di Poliklinik Gigi RSUD Kota Tasikmalaya terbanyak pada kategori pekerjaan memerlukan penampilan sebanyak 26 orang (76,5\%).

5. Sosial ekonomi pasien kehilangan gigi tetap di Poliklinik Gigi RSUD Kota Tasikmalaya terbanyak pada kategori pendapatan tinggi sebanyak 20 orang $(58,8 \%)$.

6. Ada hubungan karakteristik pasien (umur, jenis kelamin, pendidikan, jenis pekerjaan, sosial ekonomi) dengan gigi tiruan sebagian lepasan di Poliklinik Gigi RSUD Tasikmalaya.

\section{SARAN}

Pasien lebih menggali informasi tentang gigi tiruan sehingga menimbulkan keyakinan ketika pemakaian gigi tiruan secara medis tidak hanya dilihat dari penampilan saja. 


\section{DAFTAR PUSTAKA}

Depdiknas., 2011. Sistem Pendidikan Indonesia, www.depdiknas.go.id, diakses tanggal 28 Maret 2013.

Hendrartini., 1995. Evaluasi Status Kebersihan Gigi Murid SD UKGS Tahap III Yang dikelola Siswa Sekolah Pengatur Rawat Gigi (SPRG), Majalah IImiah Dies Natalis FKG UGM Ceril $V$ Ed. Khusus Lustrum ke VII, FKG Universitas Gadjah Mada, Yogyakarta.

Hurlock, EB., 2004. Psikologi Perkembangan. Edisi ke-5. Jakarta: Erlangga.www.google.book, diakses tanggal 25 Mei 2013.

Janjua, dkk., 2014. Dental caries and periapical abscess. http://globalskinatlas.com/ imagedetail.cfm?topLevellD=1347\&ima gelD $=3176 \&$ did .

Keraf., 2001. IImu Pengetahuan sebuat Tinjauan Filosofis, Penerbit Kanisius Yogyakarta.

Mc. Cord., 2004. Treatment of Endentulous Patients, Churchill Livingstone, USA.

Notoatmodjo., 2003. IImu Kesehatan Masyarakat. Jakarta. PT. Rineka Cipta.

------------., 2007. Promosi Kesehatan Teori dan Ilmu Perilaku. Jakarta: Rineka Cipta.

Notoatmodjo., 2010. Metodologi Penelitian Kesehatan. Jakarta: PT. Rineka Cipta.

Rikmasari., 2010. Pilih Gigi Palsu sesuai Kondisi Anda, Kedokteran Gigi, Bandung.

Riskesdas., 2007. Riset Kesehatan Dasar, Badan Penelitian dan Pengembangan Kesehatan, Departemen Kesehatan, Republik Indonesia. Jakarta. 